\title{
Variability in human semen content and its potential effects in the female reproductive tract
}

\author{
Shawn Keogan ${ }^{1,2 \dagger}$, Karl Siegert $^{3 \dagger}$, Brian Wigdahl $^{1,2,4}$ and Fred C. Krebs ${ }^{1,2^{*}}$ \\ *Correspondence: fred.krebs@drexelmed.edu

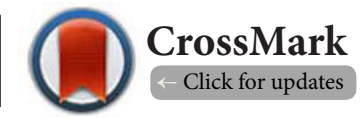 \\ 'These authors contributed equally to this work. \\ 'Department of Microbiology and Immunology, Drexel University College of Medicine, Philadelphia, Pennsylvania, USA. \\ ${ }^{2}$ Institute for Molecular Medicine and Infectious Disease, Drexel University College of Medicine, Philadelphia, Pennsylvania, USA. \\ ${ }^{3}$ Department of Biology, College of Arts \& Sciences, Drexel University, Philadelphia, Pennsylvania, USA. \\ ${ }^{4}$ Sidney Kimmel Cancer Center, Thomas Jefferson University, Philadelphia, Pennsylvania, USA.
}

\begin{abstract}
Human semen is a complex medium containing high concentrations of cytokines, chemokines, and growth factors that play key roles in orchestrating immune responses during reproduction. These factors are essential to establishing conditions that facilitate fertilization and embryogenesis through modulation of local immune responses in the female reproductive tract. Typically, semen initiates a biphasic process of inflammation that is gradually resolved, leading to immune cell recruitment pivotal to clearing excess sperm and establishing tolerance of the fetal allograft. However, the identity and concentration of factors found in semenmay be altered in the male reproductive tract as a consequence of sexually transmitted infections and infertility conditions. As a result, imbalances in semen content can skew the secretory response of the cervicovaginal epithelium after deposition during heterosexual intercourse, which may distort local immune activity and lead to embryo rejection or enhanced pathogen transmission. Recognizing the array of factors contained in semen and the degree to which they vary is an essential part of understanding the impact of variations in semen content on reproductive biology and the transmission of sexually transmitted disease pathogens.
\end{abstract}

Keywords: Semen, cytokine, growth factors, female reproductive tract, variation

\section{Introduction}

There is a growing body of information in the general area of reproductive biology that has indicated a more active role for semen in the female reproductive tract (FRT) than initially suspected. Areview of semen and female genital tract secretions in the context of microbicide development cited unpublished experiments that suggested the presence of factors in seminal fluid that were likely modulating innate immune responses in the FRT [1]. More recent studies involving FRT-derived epithelial cells exposed to semen suggested that transforming growth factor beta (TGF- $\beta$ ), present in very high concentrations within semen, may be responsible for directing a local immune response within the FRT that favors embryo implantation [2]. It was concluded that TGF- $\beta$ was a major factor responsible for initiating the early, local inflammatory response through the induction of granulocyte-macrophage colony-stimulating factor (GM-CSF) and interleukin 6 (IL-6) expression from cervical epithelial cells $[2,3]$. Additional studies demonstrated that seminal TGF- $\beta$ was also responsible for inducing a local antiinflammatory response that favored tolerance of the paternal antigens and embryo implantation during the resolution phase of inflammation [4]. These studies strongly suggest that the introduction of semen has a profound effect on the immunological environment within the FRT, which may influence both reproduction and heterosexual disease transmission.

Gaining an understanding of the effects of semen within the FRT is confoundedby multiple factors, not the least of which is the complexity presented by the involvement of two separate systems-the male reproductive tract (MRT) and the FRT-each with their own anatomical and immunological aspects to consider. Semen is a complex mixture of cytokines, chemokines, and biologically active molecules. The concentration of these factors is influenced by donor-specific variables at multiple levels (health, diet, age, infection, and substance abuse) and can be further altered as a consequence of infertility. Studies have demonstrated significant differences in seminal cytokine 
and chemokine content between infertile and fertile men, which can vary depending on the type of infertility condition and disease progression. The activities of these factors once deposited in the FRT add another level of variability. The FRT, in turn, is subject to its own unique set of variables, including hormones, age, and conditions associated with concurrent infections or other physiological conditions [3]. Studies of semen-mediated effects will need to identify which responses are separately controlled by female ormale factors, and which outcomes result from combined interactions.

The goal of this review is to documentthe variability of semen and semen-derived factors and explore their roles in initiating the local immune responses within the FRT that are key to successful reproduction and prevention of infection.

\section{Review}

\section{Semen has a complex and variable composition}

Mature sperm cells in the testes that are ready for ejaculation pass through the epididymis where prostate fluid, which is rich in proteins and other factors such as citric acid and zinc [5], is added (Figure 1). Prior to release, semen is further augmented by fluid from the seminal vesicles, which are responsible for establishing the alkaline $\mathrm{pH}$ of semen [5]. The average volume of seminal fluid ejaculated is $3.5 \mathrm{ml}$, but can range anywhere from $100 \mu \mathrm{l}$ to $11 \mathrm{ml}$ [6]. Just as the total volume varies, the concentrations of biologically active factors, including hormones, mucin, cadaverine, putrescine, spermine, enzymes, cytokines/chemokines, fructose, and vitamin $D$, and other soluble factors present in seminal fluid [7], can also vary significantly not only between donors but also within one individual over time. Semen content can also be affected by otherfactors, such as changes in fertility, age, frequency of ejaculation, infection by sexually transmitted disease (STD) pathogens, substance abuse, prescription medications, and other factors that reflect an individual's lifestyle $[\mathbf{8}, \mathbf{9}]$. To address the elements of intra- and inter-donor variability, experiments requiring semen have either used large cohorts or often incorporated combined seminal fluid samples from five or more donors, creating working samples with greater volume and content more representative of the "average" male semen content.

Studies of male infertility have provided numerous opportunities to assess the concentrations of biologically active factors contained in semen. These studies have clearly shown that (i) semen contains a diverse and wide range of immunomodulatory factors that likely participate in reproduction as well as pathogen defense, and (ii) the concentrations of these factors can vary greatly with changes in reproductive health or infection.

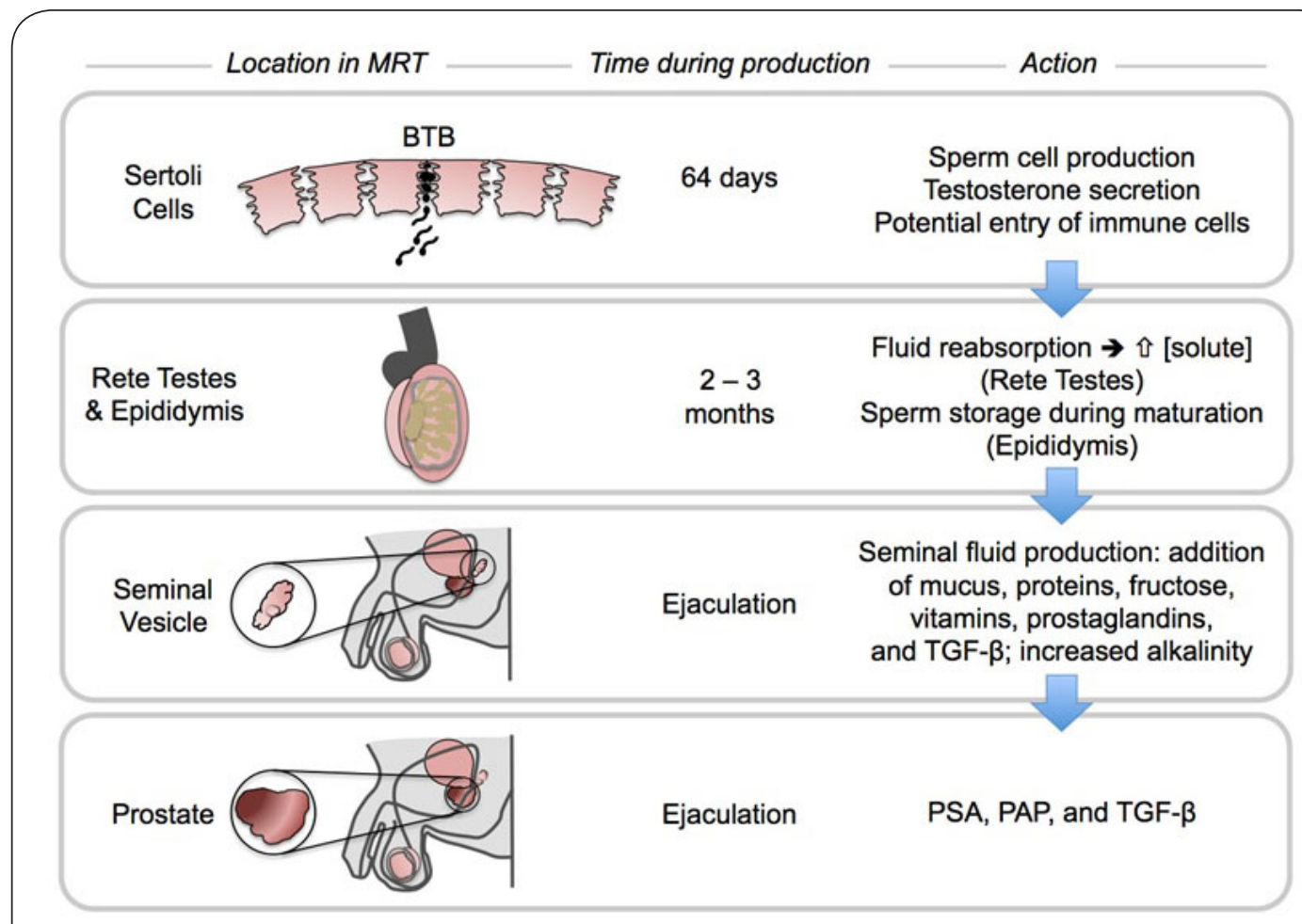

Figure 1. Flow diagram of semen production within the human male reproductive tract (MRT). This schematic representation of the MRT illustrates the tissues involved in semen production within the MRT, the timing of semen production, and the points at which seminal fluid volume and content are altered. BTB, blood-testes barrier; PSA, prostate-specific antigen; PAP, prostatic acid phosphatase; TGF- $\beta$, transforming growth factor beta. 
Table 1 is a compilation of biological factors shown to vary in concentration with MRT pathology. Details about their concentrations, clinical conditions under which they were collected, and the degree to which their concentrations varied with MRT pathology are available in Supplementary Tables S1 through $\mathbf{5 5}$ in Supplementary Information. Some of these factors are highlighted in this review.

\section{Factors in semen modulate immunity essential to establishing fertilization}

Factors in seminal fluid must be present at optimal concentrations in order to achieve successful reproduction. Fertility is more than just a function of sperm count; the components of seminal fluid not only control the concentration of sperm in semen, but also influence the quality of the spermatozoa and alter the environment within the FRT to orchestrate tolerance of the paternal antigens in support of fertilization and embryo implantation. Many studies of healthy human males, infertile human males, and animals have provided insights into the intricate processes that take place in the FRT during reproduction.

Events begin with the deposition of semen in the FRT. Initially, semen is recognized by the local female innate immune system as a foreign entity due to the presence of paternalantigens and MHC class I and II on spermatozoa [10]. As a result, an inflammatory reaction is incited, characterized by a massive infiltration of neutrophils that are likely recruited by the high concentrations of IL-8 (Table 1 and Supplementary Table S4) and GM-CSF (Table 1 and Supplementary Table S5) found in seminal fluid [11]. The initial phase of inflammation is important to clear excess and abnormal sperm as well as various waste products found within semen $[11,12]$. It is vital, however, that the inflammatory phase be quickly resolved, as uncontrolled inflammation could lead to the clearance of the healthy sperm cells by neutrophils and result in a reduced capacity for fertilization. In order to suppress the female im- mune system and allow the paternal antigens to go unrecognized, a state of tolerance must be induced, likely mediated by the pleiotropic cytokine TGF- $\beta$. Both pro-TGF- $\beta$ and active TGF- $\beta$ are secreted into semen by the seminal vesicles and prostate, and arepresent at very high concentrations within the seminal fluid (Table 1 and Supplementary Table S3) $[11,13]$.

In combination with seminal IL-15, TGF- $\beta$ tilts the immune balance from the initial Th1 response to a Th2 type response through the induction of regulatory $T\left(T_{\text {reg }}\right)$ cell differentiation of $\mathrm{T}$ cells from the periphery $[4,13]$. As $\mathrm{T}_{\text {reg }}$ cells increase in number, a concurrent opposing shift in the local immune cell population results in the suppression of Th17 switching, the overabundance of which has been correlated with preeclampsia [14]. Additional studies suggest that semen may further bias a type 2 response by inducing the production of type 2 cytokines from local and intraepithelial T cells and dendritic cells (DCs), possibly through semen-associated prostaglandins $[15,16]$. These studies highlight the active role of semen in inducing the immune changes that prevent the semi-allograft fetus from being recognized as a foreign antigen and protect it from clearance [11].

TGF- $\beta$, however, is in no way the only important immunomodulatory factor found in semen. Another important suppressive component found in high concentrations is prostaglandin $\mathrm{E}_{2}\left(\mathrm{PGE}_{2}\right)$, which also originates in the seminal vesicles (Table 1 and Supplementary Table S1). Prostaglandins are key in dampening the immune response through inhibition of macrophage cytokine production and T cell proliferation $[11-13,17,18]$. Like IL-15, PGE 2 also works in combination with TGF- $\beta$ to promote tolerance of paternal and fetal antigens, contributing to the differentiation and expansion of $\mathrm{T}_{\text {reg }}$ cells in the FRT $[4,13]$. Abnormalities in any one of the functions directed by the factors in seminal fluid, such as embryo implantation and development, could lead to a state of dysregulation, as evidenced by the many types of male infertility that have been identified and described in literature (Table 1).

Table 1. Human semen contains numerous biologically active factors that change with MRT pathology.

\begin{tabular}{|c|c|}
\hline $\begin{array}{l}\text { Miscellaneous Biologically Active Factors } \\
\text { (see also Supplementary Tables S1) }\end{array}$ & $\begin{array}{l}\text { Sperm Count, Adrenaline, Chloride, Citrate, Dopamine, E2, FSH, Fructose, } \\
\text { Glucose, LH, Magnesium, Noradrenaline, PAP, PGE2, Potassium, PRL, Putrescine, } \\
\text { Sodium, Sodium Citrate, Spermidine, Spermine, Testosterone, Vitamin A, Vitamin } \\
\text { C, Vitamin E, Zinc }\end{array}$ \\
\hline $\begin{array}{l}\text { Pro-inflammatory Cytokines } \\
\text { (see also Supplementary Tables S2) }\end{array}$ & IFN- $\alpha$, IFN- $\gamma$, IL-1 $\alpha$, IL-1 $\beta$, IL-6, IL-12, IL-17, IL-18, IL-23, MIF, TNF- $\alpha$ \\
\hline $\begin{array}{l}\text { Anti-inflammatory Cytokines } \\
\text { (see also Supplementary Tables S3) }\end{array}$ & IL-5, IL-10, TGF- $\beta(1,2$, and 3$)$ \\
\hline $\begin{array}{l}\text { Chemokines } \\
\text { (see also Supplementary Tables S4) }\end{array}$ & IL-8, IP-10, I-TAC, MCAF/MCP-1, MIG, MIP- $1 \alpha$, MIP-1 $\beta$, RANTES, SDF- $1 \alpha$ \\
\hline $\begin{array}{l}\text { Growth and Signaling Factors } \\
\text { (see also Supplementary Tables S5) }\end{array}$ & BDNF, EGF, G-CSF, GM-CSF, IL-2, sIL-2R, sIL-6R, IL-7, IL-11, IL-13, NGF, VEGF \\
\hline
\end{tabular}

The table lists biologically active factors in semen found to vary in concentration with disease and infection. For more details, including concentration ranges, diseases and pathologies associated with changes in each factor, and source references, refer to Supplementary Tables S1 through Supplementary Tables S5. 
Keogan et al. Journal of Reproductive Biology and Health 2016,

http://www.hoajonline.com/journals/pdf/2054-0841-4-1.pdf

doi: 10.7243/2054-0841-4-1

Changes in semen-associated immune factors correlated with infertility in the MRT

Due to the complex composition of seminal fluid, male infertility may be correlated with an increase or decrease in a multitude of factors noted for their immunomodulatory activities (Table 1 ). The presence of interleukin $1 \beta$ (IL-1 $\beta$ ), a pro-inflammatory cytokine, has been inversely correlated with sperm motility (Table 1 and Supplementary Table S2). Similarly, increases in interleukin 6 (IL-6), possibly secreted by lymphocytes in semen or hormonally regulated Sertoli cells in the MRT, havebeen correlated with decreases in sperm count and motility, as well as decreases in semen volume (Table 1 and Supplementary Table S2) [19-21]. Interleukin 8 (IL-8), a chemotactic cytokine found at higher levels in the semen of individuals diagnosed with infertility due to leukocytospermia, has been suggested to be responsible for recruiting excessive numbers of white blood cells (WBCs), resulting in abnormally high T-lymphocyte counts in semen as well as a decrease in spermatozoa viability (Table 1 and Supplementary Table S4) [19]. Increased IL-8 has also been correlated with increases in pro-inflammatory cytokines interleukin 1a (IL-1a) (Table 1 and Supplementary Table S2) and granulocyte colony-stimulating factor (G-CSF) (Table 1 and Supplementary Table S5), which may be released into semen by macrophages or endothelial cells lining the MRT. IL-1 $a$ and G-CSF are responsible for activating $T$ cell proliferation and stimulating neutrophil production, which are both key to eliciting an inflammatory immune response [22]. Increased interleukin 18 (IL-18), which was shown to be present at higher concentrations in semen of men suffering from combined infertility/urogenital infections, was correlated with decreased sperm concentration and mobility (Table 1 and Supplementary Table S2) [23]. Several studies have noted an increase in tumor necrosis factoralpha (TNF- $\alpha$ ) in semen in conjunction with low or undetectable sperm counts (Table 1 and Supplementary Table S2). TNF- $a$ has also been correlated with reductions in testosterone and sperm motility, alterations in sperm morphology, and increases in reactive oxygen species (ROS) $[\mathbf{2 0}, \mathbf{2 1}, \mathbf{2 4}]$. Similarly, increases in interferongamma (IFN- $\gamma$ ) across multiple infertility conditions werealso associated with decreased sperm count, motility, and morphology (Table 1 and Supplementary Table S2) [20].

The protein monocyte chemotactic and activating factor (MCAF) provides a particularly illustrative example of a biological factor contained in semen that may impact reproductive fitness through variations in concentration. Levels of MCAF in seminal fluid of men with leukocytospermia are increased over those of other infertile-type conditions or fertile males (Table 1 and Supplementary Table S4), indicating that specific infertility diagnoses can be associated with specific cytokine concentrations [25]. Increased levels of MCAF may originate from monocytes, endothelial cells, or fibroblasts present in the MRT and be involved in protecting the reproductive tract from infection bybacterial pathogens [25]. The role of MCAF in reproductive biology, however, is not limited to the male. It has been speculated that once semen has been deposited into the FRT, MCAF may be responsible for the local recruitment and activation of monocytes, which are important in clearing excess sperm [25]. In leukocytospermia, MCAF stimulation has also been associated with the release of IL- 6 from monocytes, which in conjunction with increased IL-8, results in further activation and differentiation of monocytes into macrophages and recruitment of neutrophils [25]. An increase in the local presence and activation of phagocytes could result in increased clearance of sperm cells, hindering fertility.Cumulatively, these factors and effects directly influence mechanisms that may alter local immune responses that affect not only reproductive events, but may also contribute to the risk of STD pathogen infection within the FRT [3].

\section{Effects of seminal factors in the FRT}

In addition to its direct influence on immune cells, semen can also have indirect effects on the immune response mediated through the epithelial cells lining the reproductive tract of the female. While the FRT is a large and complex environment, the epithelial lining can essentially be broken down into three main regions: the vagina, which has the largest surface area in the FRT and is characterized by a squamous epithelium that can be up to 25 cell layers thick; the ectocervix, which encompasses the portion of the epithelium that transitions from a multi-layer squamous phenotype into a simple columnar phenotype characterized by low tight junction expression; and the endocervix, which is describedas a single columnar epithelial layer with high levels of tight junction expression [26]. Interestingly, our group and others have observed that each of these regions is not only unique in phenotype or tight junction expression, but in responsiveness to stimuli, such as seminal fluid, revealing that the epithelium is more than just a mechanical barrier -it is also a dynamic tissue [27]. In fact, seminal fluid seems to elicit this response on tight junctions on epithelial cells in a variety of environments [28]. When epithelial cells derived from the three main regions of the reproductive tract were incubated with seminal fluid in submerged culture, a wide array of factors were released, the most predominant of which were the inflammatory cytokines $[16,27]$. However, the concentrations and specific cytokine release profiles were unique to each region [27]. In one study, cells derived from the ectocervix were the most responsive compared to cells of the vaginal tract. These results suggest that the vaginal epithelium, which is regularly exposed to bacteria, pathogens, irritants, and foreign entities (including semen), has a greater tolerance for damage or inflammatory stimuli [27]. The cervix, on the other hand, is considered to be essentially sterile due to its remote placement relative to the vaginal opening, and is protected from external insults by a layer of mucus. Because this region is exposed to a lower level of stimuli relative the vaginal epithelium, the tolerance of the epithelium might be lower and its responsiveness to 
insults correspondingly higher [27]. Studies have shown that even in the cervix there are regional differences, with the endocervix (higher up in the FRT) having a greater response to foreign stimuli [29]. Perhaps this robust response is due to the fact that the upper cervical region sees fewer foreign stimuli than the lower region and stands poised to provide a more effective response to stop colonization of the upper cervix [29].

Factors that are released by epithelial cells in a basolateral direction in response to apical exposure to semen also orchestrate reproductive inflammatory/tolerance events by influencing local immune cells [30]. For example, the transition of uterine natural killer cells ( $\mathrm{UNK}$ ) from a cytotoxic to a "helper" phenotype is essential to fetal development [31], insofar as having uNKs recognize fetal development as "self," or non-foreign, and therefore not attacking the developing fetus through induced tolerance. During embryogenesis, uNK cells release IFN- $\gamma$ to aid in angiogenesis and vascularization of the uterus in order to support the developing fetus [31,32]. Although it remains controversial, the shift in uNK phenotype leading to tolerance may be induced by IL-15 and IL-7 [33]. Release of IL-15 from the epithelium is increased 22-fold in the subepithelial space as early $4 \mathrm{~h}$ post-semen exposure [34]. As mentioned previously, the combination of IL-15 and TGF- $\beta$ increases T-cell switching to a $T_{\text {reg }}$ phenotype, further contributing to key events that initiate fetal tolerance [13]. Interestingly, the number of $\mathrm{T}_{\text {regs }}$ and $\mathrm{uNK}$ cells present in the uterus are higher relative to the peripheral blood, implicating the intensive role these cell types play in local reproductive immunity [35]. The shift from inflammation to tolerance in the FRT during semen exposure has been likened to the changes that occur in the tumor microenvironment, both of which provide protection from immune clearance and allow cells to proliferate in a similar manner [36]. Combined, the activity of the reproductive epithelium added to the effects of factors contained in semen creates a biphasic local immune response that is key to clearing excess sperm and essential to developing tolerance to the nascent fetus in the FRT during reproduction.

In the context of pathogen transmission, the same factors that are important to reproduction may also contribute to susceptibility to sexually transmitted infections (STIs). When $\mathrm{CD} 4+\mathrm{T}$ cells were incubated directly in seminal plasma,there was anobserved increase in CCR5 surface expression,resulting in preferential R5 infection in the presence ofhuman immunodeficiency virus type 1 (HIV-1) [37]. There is also evidence that the same type 2 responses that are responsible for tolerance of sperm may also protect the virus from clearance. Prostaglandins in semen that drive a local type 2 response, as described previously, may also inhibit IL-12 release and upregulate IL-10 production by DCs, possibly reducing the capacity for clearance of virus [15]. Combined with the data demonstrating that IL-7 -which is increased in the seminal fluid of HIV-1-infected males and also released by the epi- thelium after semen exposure-can enhance HIV-1 transmission toT cells in cervicovaginal explants [38], these findings further highlight the potential effects of combined factors from both seminal fluid and the reproductive epithelium in directly modulating transmission of HIV-1, as well as other STD pathogens.

\section{Future directions}

Studies that strive for a better understanding of the interplay between seminal factors and the FRT will provide new insights into reproductive biology as well as failures in reproduction attributable to disease or infection. Such studies will also give rise to the development of new model systems in which critical aspects of this important interplay can be readily manipulated and studied. For example, in vitro studies using a simple model consisting of semen and cervicovaginal epithelial cells may attribute a failure to modulate key innate immune responses in a timely manner to decreased concentrations of TGF- $\beta$ in seminal plasma. Such information could be the catalyst for the development of new drugs that effectively treat infertility. This review highlights the importance of the major constituents of semen and provides the first stepping stones toward future experiments of this nature.

Outside of reproduction, immunomodulatory factors in semen may also affect key events that influence the transmission of STD pathogens, such as HIV-1, resulting in an increased or decreased risk of male-to-female transmission. Having greater knowledge about the dynamics of biologically active factors in semen will increase our understanding of not only reproductive biology, but also STD pathogen transmission. More detailed information about the role of semen in modulating the risk of pathogen transmission will likely reveal new strategies for preventing STD acquisition by women. For example, a greater understanding of seminal factors that result in FRT inflammation and the chemotaxis of HIV-1-susceptible immune cells to the cervicovaginal epithelium may provide a path toward the development of next generation topical microbicides that reduce semen-associated immune cell recruitment and reduce the risk of male-to-female HIV-1 transmission. It is our hope that this review will also serve as a supporting resource for these types of studies.

\section{Conclusions}

Semen is a biologically active fluid capable of orchestrating and influencing immune responses within the FRT. Some of the numerous agents in semen that profoundly affect the immunological environment of the FRT include cytokines, chemokines, growth factors, and other biologically active molecules. These components disrupt the normal immune response of the female, which may leave her susceptible to further complications. Although the MRT is highly compartmentalized, semen composition can be influenced by reproductive tract disease and conditions outside the MRT, resulting in changes in concentration of key seminal compo- 
nents that are important in guiding reproductive processes in the FRT. Significant changes in factors present in semen may result in infertility or reproductive dysfunction. Similarly, indirect changes induced by semen, such as the release of factors by the epithelium or changes in immune cell populations, may also influence the delicate pro-inflammatory and anti-inflammatory phases of reproduction.

\section{Additional files}

\section{Supplementary Table S1 \\ Supplementary Table S2 \\ Supplementary Table S3 \\ Supplementary Table S4 \\ Supplementary Table S5}

Competing interests

The authors declare that they have no competing interests.

Authors' contributions

\begin{tabular}{|l|c|c|c|c|}
\hline Authors' contributions & SK & KS & BW & FCK \\
\hline Research concept and design & $\checkmark$ & $\checkmark$ & $\checkmark$ & $\checkmark$ \\
\hline Collection and/or assembly of data & $\checkmark$ & $\checkmark$ & -- & -- \\
\hline Data analysis and interpretation & -- & -- & -- & -- \\
\hline Writing the article & $\checkmark$ & $\checkmark$ & -- & -- \\
\hline Critical revision of the article & $\checkmark$ & $\checkmark$ & $\checkmark$ & $\checkmark$ \\
\hline Final approval of article & -- & -- & $\checkmark$ & $\checkmark$ \\
\hline Statistical analysis & -- & -- & -- & -- \\
\hline
\end{tabular}

Acknowledgement and funding

These studies were supported by faculty development funds provided to Fred C. Krebs by the Department of Microbiology and Immunology and the Institute for Molecular Medicine and Infectious Disease at the Drexel University College of Medicine. The funding sources had no involvement in the preparation of this manuscript.

\section{Publication history}

Editors: Erich Cosmi, University of Padua, Italy.

Received: 18-Apr-2016 Final Revised: 19-May-2016

Accepted: 25-May-2016 Published: 01-Jun-2016

\section{References}

1. Herold BC, Mesquita PM, Madan RP and Keller MJ. Female genital tract secretions and semen impact the development of microbicides for the prevention of HIV and other sexually transmitted infections. Am J Reprod Immunol. 2011; 65:325-33. | Article | PubMed Abstract | PubMed FullText

2. Sharkey DJ, Macpherson AM, Tremellen KP, Mottershead DG, Gilchrist RB and Robertson SA. TGF-beta mediates proinflammatory seminal fluid signaling in human cervical epithelial cells. J Immunol. 2012; 189:102435. | Article | PubMed

3. Keogan S, Siegert K, Wigdahl B and Krebs FC. Critical Review: Immunomodulation by Seminal Factors and Implications for Male-toFemale HIV-1 Transmission. J Acquir Immune Defic Syndr. 2015; 69:1317. | Article | PubMed

4. Robertson SA, Guerin LR, Bromfield JJ, Branson KM, Ahlstrom AC and Care AS. Seminal fluid drives expansion of the CD4+CD25+ T regulatory cell pool and induces tolerance to paternal alloantigens in mice. Biol Reprod. 2009; 80:1036-45. | Article | PubMed Abstract | PubMed FullText

5. Taylor S, Ferguson NM, Cane PA, Anderson RM and Pillay D. Dynamics of seminal plasma HIV-1 decline after antiretroviral treatment. AIDS. 2001; 15:424-6. | PubMed

6. Mauck CK. Biomarkers of semen exposure. Sex Transm Dis. 2009; 36:S81-3. | Article | PubMed

7. Owen DH and Katz DF. A review of the physical and chemical properties of human semen and the formulation of a semen simulant. J Androl. 2005; 26:459-69. | Article | PubMed

8. Levitas E, Lunenfeld E, Weisz N, Friger M and Potashnik G. Relationship between age and semen parameters in men with normal sperm concentration: analysis of 6022 semen samples. Andrologia. 2007; 39:45-50. | Article | PubMed

9. Diemer T, Huwe P, Ludwig M, Hauck EW and Weidner W. Urogenital infection and sperm motility. Andrologia. 2003; 35:283-7. | Article | PubMed

10. Fijak $\mathrm{M}$ and Meinhardt A. The testis in immune privilege. Immunol Rev. 2006; 213:66-81. | Article | PubMed

11. Munoz-Suano A, Hamilton AB and Betz AG. Gimme shelter: the immune system during pregnancy. Immunol Rev. 2011; 241:20-38. | Article | PubMed

12. Robertson SA, Ingman WV, O'Leary S, Sharkey DJ and Tremellen KP. Transforming growth factor beta--a mediator of immune deviation in seminal plasma. J Reprod Immunol. 2002; 57:109-28. | Article | PubMed

13. Robertson SA, Guerin LR, Moldenhauer LM and Hayball JD. Activating $T$ regulatory cells for tolerance in early pregnancy - the contribution of seminal fluid. J Reprod Immunol. 2009; 83:109-16. | Article | PubMed

14. Darmochwal-Kolarz D, Kludka-Sternik M, Tabarkiewicz J, Kolarz B, Rolinski J, Leszczynska-Gorzelak B and Oleszczuk J. The predominance of Th17 lymphocytes and decreased number and function of Treg cells in preeclampsia. J Reprod Immunol. 2012; 93:75-81. | Article | PubMed

15. Bronson R. Biology of the male reproductive tract: its cellular and morphological considerations. Am J Reprod Immunol. 2011; 65:212-9. Article | PubMed

16. Gutsche S, von Wolff M, Strowitzki T and Thaler CJ. Seminal plasma induces mRNA expression of IL-1beta, IL- 6 and LIF in endometrial epithelial cells in vitro. Mol Hum Reprod. 2003; 9:785-91. | Article | PubMed

17. Gerozissis K, Jouannet $P$, Soufir JC and Dray F. Origin of prostaglandins in human semen. J Reprod Fertil. 1982; 65:401-4. | Article | PubMed

18. Skibinski G, Kelly RW, Harrison CM, McMillan LA and James K. Relative immunosuppressive activity of human seminal prostaglandins. J Reprod Immunol. 1992; 22:185-95. | Article | PubMed

19. Naz RK and Kaplan P. Increased levels of interleukin- 6 in seminal plasma of infertile men. J Androl. 1994; 15:220-7. | Article | PubMed

20. Seshadri S, Bates M, Vince $G$ and Jones DI. The role of cytokine expression in different subgroups of subfertile men. Am J Reprod Immunol. 2009; 62:275-82. | Article | PubMed

21. Martinez-Prado E and Camejo Bermudez MI. Expression of IL-6, IL-8, TNF-alpha, IL-10, HSP-60, anti-HSP-60 antibodies, and anti-sperm antibodies, in semen of men with leukocytes and/or bacteria. $\mathrm{Am} \mathrm{J}$ Reprod Immunol. 2010; 63:233-43. | Article | PubMed

22. Maegawa M, Kamada M, Irahara M, Yamamoto S, Yoshikawa S, Kasai Y, Ohmoto $\mathrm{Y}$, Gima H, Thaler $\mathrm{CJ}$ and Aono T. A repertoire of cytokines in human seminal plasma. J Reprod Immunol. 2002; 54:33-42. | Article | PubMed

23. Matalliotakis IM, Cakmak H, Fragouli Y, Kourtis A, Arici A and Huszar G. Increased IL-18 levels in seminal plasma of infertile men with genital tract infections. Am J Reprod Immunol. 2006; 55:428-33. | Article | PubMed

24. Qian L, Sun G, Zhou B, Wang G, Song J and He H. Study on the relationship between different cytokines in the semen of infertility patients. Am J Reprod Immunol. 2011; 66:157-61. | Article | PubMed

25. Shimoya K, Matsuzaki N, Ida N, Okada T, Taniguchi T, Sawai K, Itoh S, Ohashi K, Saji F and Tanizawa O. Detection of monocyte chemotactic and activating factor (MCAF) and interleukin (IL)- 6 in human seminal plasma and effect of leukospermia on these cytokine levels. Am J Reprod Immunol. 1995; 34:311-6. | Article | PubMed 
Keogan et al. Journal of Reproductive Biology and Health 2016, http://www.hoajonline.com/journals/pdf/2054-0841-4-1.pdf

26. Blaskewicz CD, Pudney J and Anderson DJ. Structure and function of intercellular junctions in human cervical and vaginal mucosal epithelia. Biol Reprod. 2011; 85:97-104. | Article | PubMed Abstract | PubMed FullText

27. Sharkey DJ, Macpherson AM, Tremellen KP and Robertson SA. Seminal plasma differentially regulates inflammatory cytokine gene expression in human cervical and vaginal epithelial cells. Mol Hum Reprod. 2007; 13:491-501. | Article | PubMed

28. Pierucci-Alves F, Yi S and Schultz BD. Transforming growth factor beta 1 induces tight junction disruptions and loss of transepithelial resistance across porcine vas deferens epithelial cells. Biol Reprod. 2012; 86:36. | Article | PubMed Abstract | PubMed FullText

29. Fichorova RN, Desai PJ, Gibson FC, 3rd and Genco CA. Distinct proinflammatory host responses to Neisseria gonorrhoeae infection in immortalized human cervical and vaginal epithelial cells. Infect Immun. 2001; 69:5840-8. | Article | PubMed Abstract | PubMed FullText

30. Robertson SA. Seminal plasma and male factor signalling in the female reproductive tract. Cell Tissue Res. 2005; 322:43-52. | Article | PubMed

31. Riley JK and Yokoyama WM. NK cell tolerance and the maternal-fetal interface. Am J Reprod Immunol. 2008; 59:371-87. | Article | PubMed

32. Zhang J, Chen Z, Smith GN and Croy BA. Natural killer cell-triggered vascular transformation: maternal care before birth? Cell Mol Immunol. 2011; 8:1-11. | Article | PubMed Abstract | PubMed FullText

33. Croy BA, He H, Esadeg S, Wei Q, McCartney D, Zhang J, Borzychowski A, Ashkar AA, Black GP, Evans SS, Chantakru S, van den Heuvel M, Paffaro VA, Jr. and Yamada AT. Uterine natural killer cells: insights into their cellular and molecular biology from mouse modelling. Reproduction. 2003; 126:149-60. | Article | PubMed Abstract | PubMed FullText

34. Kitaya K, Yasuda J, Yagi I, Tada Y, Fushiki S and Honjo H. IL-15 expression at human endometrium and decidua. Biol Reprod. 2000; 63:683-7. I Article | PubMed

35. Santoni A, Carlino C, Stabile $\mathrm{H}$ and Gismondi A. Mechanisms underlying recruitment and accumulation of decidual NK cells in uterus during pregnancy. Am J Reprod Immunol. 2008; 59:417-24. | Article | PubMed

36. Holtan SG, Creedon DJ, Haluska P and Markovic SN. Cancer and pregnancy: parallels in growth, invasion, and immune modulation and implications for cancer therapeutic agents. Mayo Clin Proc. 2009; 84:985-1000. | Article | PubMed Abstract | PubMed FullText

37. Balandya E, Sheth S, Sanders K, Wieland-Alter W and Lahey T. Semen protects CD4+ target cells from HIV infection but promotes the preferential transmission of R5 tropic HIV. J Immunol. 2010; 185:7596604. | Article | PubMed Abstract | PubMed FullText

38. Introini A, Vanpouille C, Lisco A, Grivel JC and Margolis L. Interleukin-7 facilitates HIV-1 transmission to cervico-vaginal tissue ex vivo. PLOS Pathog. 2013; 9:e1003148. | Article | PubMed Abstract | PubMed FullText

39. Matalliotakis I, Arici A, Goumenou A, Koumantakis G, Selam B, Matalliotakis $G$ and Koumantakis $E$. Distinct expression pattern of cytokines in semen of men with genital infection and oligo-teratoasthenozoospermia. Am J Reprod Immunol. 2002; 48:170-5. | Article | PubMed

40. Omu AE, al-Othman S, Mohamad AS, al-Kaluwby NM and Fernandes S. Antibiotic therapy for seminal infection. Effect on antioxidant activity and T-helper cytokines. J Reprod Med. 1998; 43:857-64. | Article | PubMed

41. Luboshitzky R, Kaplan-Zverling M, Shen-Orr Z, Nave R and Herer P. Seminal plasma androgen/oestrogen balance in infertile men. Int J Androl. 2002; 25:345-51. | Article | PubMed

42. Nikoobakht MR, Aloosh M, Nikoobakht N, Mehrsay AR, Biniaz F and Karjalian MA. The role of hypothyroidism in male infertility and erectile dysfunction. Urol J. 2012; 9:405-9. | Article | PubMed

43. Lorusso F, Palmisano M, Chironna M, Vacca M, Masciandaro P, Bassi E, Selvaggi Luigi $L$ and Depalo R. Impact of chronic viral diseases on semen parameters. Andrologia. 2010; 42:121-6. | Article | PubMed

44. Ahmad MK, Mahdi AA, Shukla KK, Islam N, Rajender S, Madhukar D, Shankhwar SN and Ahmad S. Withania somnifera improves semen quality by regulating reproductive hormone levels and oxidative stress in seminal plasma of infertile males. Fertil Steril. 2010; 94:989-96. | Article | PubMed

45. Shukla KK, Mahdi AA, Ahmad MK, Shankhwar SN, Rajender S and Jaiswar SP. Mucuna pruriens improves male fertility by its action on the hypothalamus-pituitary-gonadal axis. Fertil Steril. 2009; 92:1934-40. | Article I PubMed

46. Politch JA, Tucker L, Bowman FP and Anderson DJ. Concentrations and significance of cytokines and other immunologic factors in semen of healthy fertile men. Hum Reprod. 2007; 22:2928-35. | Article | PubMed

47. Colagar AH, Marzony ET and Chaichi MJ. Zinc levels in seminal plasma are associated with sperm quality in fertile and infertile men. Nutr Res. 2009; 29:82-8. | Article | PubMed

48. Paradisi R, Mancini R, Bellavia E, Beltrandi E, Pession A, Venturoli S and Flamigni C. T-helper 2 type cytokine and soluble interleukin-2 receptor levels in seminal plasma of infertile men. Am J Reprod Immunol. 1997; 38:94-9. | Article | PubMed

49. Seshadri S, Bates M, Vince G and Jones DI. Cytokine expression in the seminal plasma and its effects on fertilisation rates in an IVF cycle. Andrologia. 2011; 43:378-86. | Article | PubMed

50. Li C, Zheng L, Wang $C$ and Zhou X. Absence of nerve growth factor and comparison of tyrosine kinase receptor $A$ levels in mature spermatozoa from oligoasthenozoospermic, asthenozoospermic and fertile men. Clin Chim Acta. 2010; 411:1482-6. | Article | PubMed

51. Rui $\mathrm{H}$, Thomassen $\mathrm{Y}$, Oldereid NB and Purvis K. Accessory sex gland function in normal young (20-25 years) and middle-aged (50-55 years) men. J Androl. 1986; 7:93-9. | Article | PubMed

52. Fujisawa M, Fujioka H, Tatsumi N, Inaba Y, Okada H, Arakawa $\mathrm{S}$ and Kamidono $\mathrm{S}$. Levels of interferon alpha and gamma in seminal plasma of normozoospermic, oligozoospermic, and azoospermic men. Arch Androl. 1998; 40:211-4. | Article | PubMed

53. Gruschwitz MS, Brezinschek R and Brezinschek HP. Cytokine levels in the seminal plasma of infertile males. J Androl. 1996; 17:158-63. | Article | PubMed

54. Naderi AR and Safarinejad MR. Endocrine profiles and semen quality in spinal cord injured men. Clin Endocrinol (Oxf). 2003; 58:177-84. | Article I PubMed

55. Safarinejad MR, Kolahi AA and Iravani S. Evaluation of semen variables, sperm chromosomal abnormalities and reproductive endocrine profile in patients with chronic hepatitis C. BJU Int. 2010; 105:79-86. | Article | PubMed

56. Safarinejad MR. Evaluation of endocrine profile, hypothalamic-pituitarytestis axis and semen quality in multiple sclerosis. J Neuroendocrinol. 2008; 20:1368-75. | Article | PubMed

57. Kafka JK, Sheth PM, Nazli A, Osborne BJ, Kovacs C, Kaul R and Kaushic C. Endometrial epithelial cell response to semen from HIV-infected men during different stages of infection is distinct and can drive HIV-1-long terminal repeat. AIDS. 2012; 26:27-36. | Article | PubMed

58. Huleihel M, Lunenfeld E, Horowitz S, Levy A, Potashnik G, Mazor M and Glezerman M. Expression of IL-12, IL-10, PGE2, sIL-2R and sIL-6R in seminal plasma of fertile and infertile men. Andrologia. 1999; 31:283-8. | Article | PubMed

59. Leutscher PD, Pedersen M, Raharisolo C, Jensen JS, Hoffmann S, Lisse I, Ostrowski SR, Reimert CM, Mauclere P and Ullum H. Increased prevalence of leukocytes and elevated cytokine levels in semen from Schistosoma haematobium-infected individuals. J Infect Dis. 2005; 191:1639-47. | Article | PubMed

60. Lisco A, Munawwar A, Introini A, Vanpouille C, Saba E, Feng X, Grivel JC, Singh S and Margolis L. Semen of HIV-1-infected individuals: local shedding of herpesviruses and reprogrammed cytokine network. J Infect Dis. 2012; 205:97-105. | Article | PubMed Abstract | PubMed FullText

61. Berlier W, Bourlet T, Levy R, Lucht F, Pozzetto B and Delezay O. Amount of seminal IL-1beta positively correlates to HIV-1 load in the semen of infected patients. J Clin Virol. 2006; 36:204-7. | Article | PubMed

62. Ulcova-Gallova Z, Gruberova J, Vrzalova J, Bibkova K, Peknicova J, 
Keogan et al. Journal of Reproductive Biology and Health 2016, http://www.hoajonline.com/journals/pdf/2054-0841-4-1.pdf

Micanova Z and Topolcan O. Sperm antibodies, intra-acrosomal sperm proteins, and cytokines in semen in men from infertile couples. Am J Reprod Immunol. 2009; 61:236-45. | Article I PubMed

63. Dousset B, Hussenet F, Daudin M, Bujan L, Foliguet B and Nabet P. Seminal cytokine concentrations (IL-1beta, IL-2, IL-6, sR IL-2, sR IL-6), semen parameters and blood hormonal status in male infertility. Hum Reprod. 1997; 12:1476-9. | Article | PubMed

64. Ochsenkuhn R, Toth B, Nieschlag E, Artman E, Friese K and Thaler CJ. Seminal plasma stimulates cytokine production in endometrial epithelial cell cultures independently of the presence of leucocytes. Andrologia. 2008; 40:364-9. | Article | PubMed

65. Sanocka D, Fraczek M, Jedrzejczak P, Szumala-Kakol A and Kurpisz M. Male genital tract infection: an influence of leukocytes and bacteria on semen. J Reprod Immunol. 2004; 62:111-24. I Article I PubMed

66. von Wolff M, Nowak O, Pinheiro RM and Strowitzki T. Seminal plasma-immunomodulatory potential in men with normal and abnormal sperm count. Eur J Obstet Gynecol Reprod Biol. 2007; 134:73-8. | Article I PubMed

67. Frenette G, Tremblay RR, Dube JY, Lazure C and Lemay M. High concentrations of the macrophage migration inhibitory factor in human seminal plasma and prostatic tissues. Arch Androl. 1998; 41:185-93. | Article | PubMed

68. Eggert-Kruse W, Kiefer I, Beck C, Demirakca T and Strowitzki T. Role for tumor necrosis factor alpha (TNF-alpha) and interleukin 1-beta (IL1beta) determination in seminal plasma during infertility investigation. Fertil Steril. 2007; 87:810-23. | Article | PubMed

69. Srivastava MD, Lippes J and Srivastava BI. Cytokines of the human reproductive tract. Am J Reprod Immunol. 1996; 36:157-66. I Article | PubMed

70. Loras B, Vetele F, El Malki A, Rollet J, Soufir JC and Benahmed M. Seminal transforming growth factor-beta in normal and infertile men. Hum Reprod. 1999; 14:1534-9. | Article | PubMed

71. Nocera M and Chu TM. Characterization of latent transforming growth factor-beta from human seminal plasma. Am J Reprod Immunol. 1995; 33:282-91. | Article | PubMed

72. Linge HM, Collin M, Giwercman A, Malm J, Bjartell A and Egesten A. The antibacterial chemokine MIG/CXCL9 is constitutively expressed in epithelial cells of the male urogenital tract and is present in seminal plasma. J Interferon Cytokine Res. 2008; 28:191-6. | Article I PubMed

73. Zheng L, Li C, Sun Y, Liu Z and Zhou X. Expression of brain-derived neurotrophic factor in mature spermatozoa from fertile and infertile men. Clin Chim Acta. 2011; 412:44-7. I Article I PubMed

74. Naz RK and Kaplan P. Effects of epidermal growth factor on human sperm cell function. J Androl. 1993; 14:240-7. I Article I PubMed

75. Paradisi R, Capelli M, Mandini M, Bellavia E, Focacci M and Flamigni C. Interleukin-2 in seminal plasma of fertile and infertile men. Arch Androl. 1995; 35:35-41. | Article | PubMed

\section{Citation:}

Keogan S, Siegert K, Wigdahl B and Krebs FC.

Variability in human semen content and its potential effects in the female reproductive tract. J Reprod Biol Health. 2016; 4:1.

http://dx.doi.org/10.7243/2054-0841-4-1 